Images In...

\title{
A bony swelling on the forehead: an uncommon manifestation of a well-known metabolic disease
}

\author{
R Santosh, ${ }^{1}$ Anil Bhansali, ${ }^{1}$ A Rajwanshi, ${ }^{2}$ Viral Shah, ${ }^{1}$ Arunanshu Behera, ${ }^{3}$ Sanjay Bhadada ${ }^{1}$ \\ ${ }^{1}$ Department of Endocrinology, PGIMER, Chandigarh, India; \\ 2Department of Pathology, PGIMER, Chandigarh, India; \\ ${ }^{3}$ Department of Surgery, PGIMER, Chandigarh, India
}

Correspondence to Anil Bhansali, anilbhansali_endocrine@rediffmail.com

\section{DESCRIPTION}

A 26-year-old female presented with progressively increasing bony swelling over her forehead for 4 months, when she was in her seventh month of gestation. She also had difficulty in walking. She had past history of renal stones. On examination she had bony and non-tender swellings on the forehead (figure 1), anterior part of head, right shoulder and behind the right ear. She had palpable

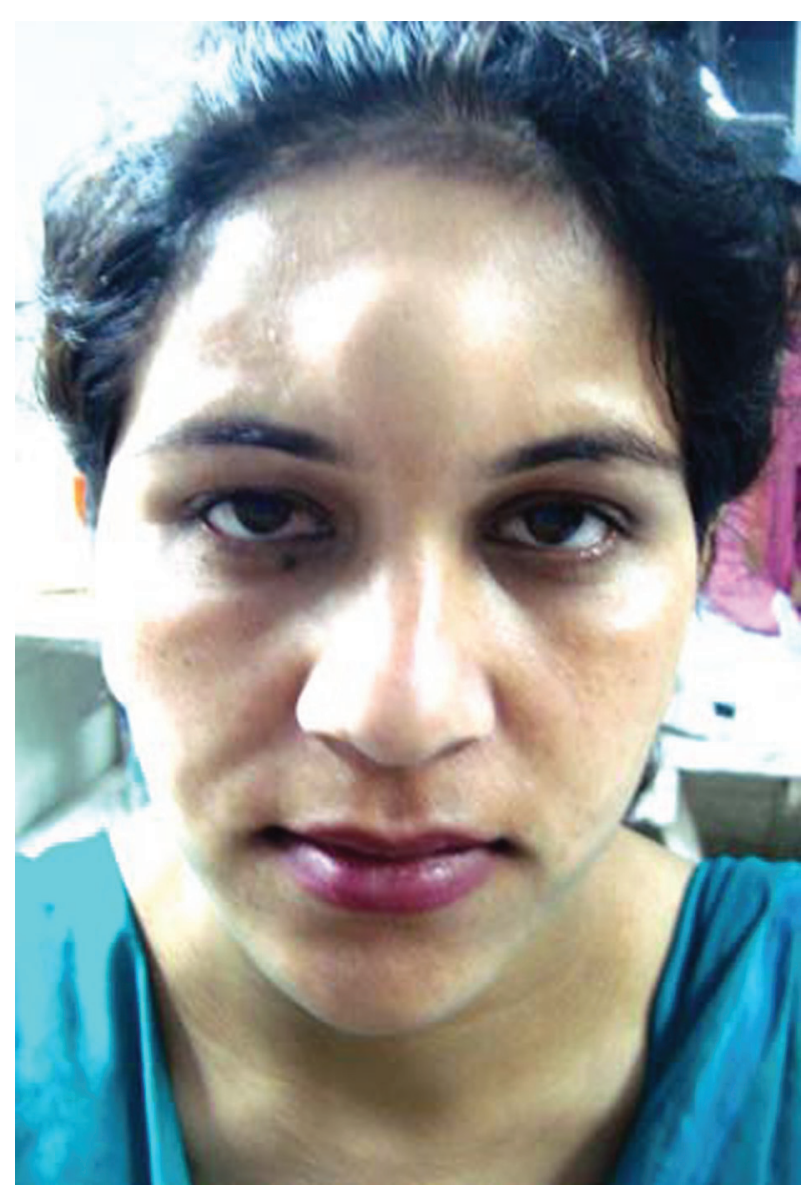

Figure 1 Clinical photograph showing bony swelling on the anterior forehead (arrowhead). nodular swelling in the left thyroid region. No other features suggestive of Multiple endocrine neoplasia. On investigations, mean albumin adjusted serum calcium was 3.32 $\mathrm{mmol} / \mathrm{l}$ (normal 2.15-2.55 mmol/l), inorganic phosphorus $0.64 \mathrm{mmol} / \mathrm{l}(0.87-1.39 \mathrm{mmol} / \mathrm{l})$, alkaline phosphatase 5.5 $\mu \mathrm{kat} / \mathrm{l}(0.67-2.02 \mu \mathrm{kat} / \mathrm{l})$, intact parathyroid hormone 1321 $\mathrm{ng} / \mathrm{l}(15-65 \mathrm{ng} / \mathrm{l})$ and 25(OH)D $111.9 \mathrm{nmol} / \mathrm{l}$ (sufficient range $75-375 \mathrm{nmol} / \mathrm{l})$. X-ray KUB revealed bilateral renal calculi. X-rays revealed osteopenia and salt and pepper appearance of the skull. Non-contrast CT scan of the head revealed multiple lytic bone lesions (figure 2). Fine needle aspiration cytology (FNAC) from the forehead lesion confirmed osteitis fibrosa cystica (figure 3). Technitium sestamibi parathyroid scan and USG neck localised a left inferior parathyroid adenoma. The patient underwent successful parathyroidectomy and histopathology confirmed parathyroid adenoma. Lytic bony lesions of the skull are not uncommon radiologically but are rare clinical findings and should alert the clinician to diagnosis of hyperparathyroidism, fibrous dysplasia, Paget's disease,

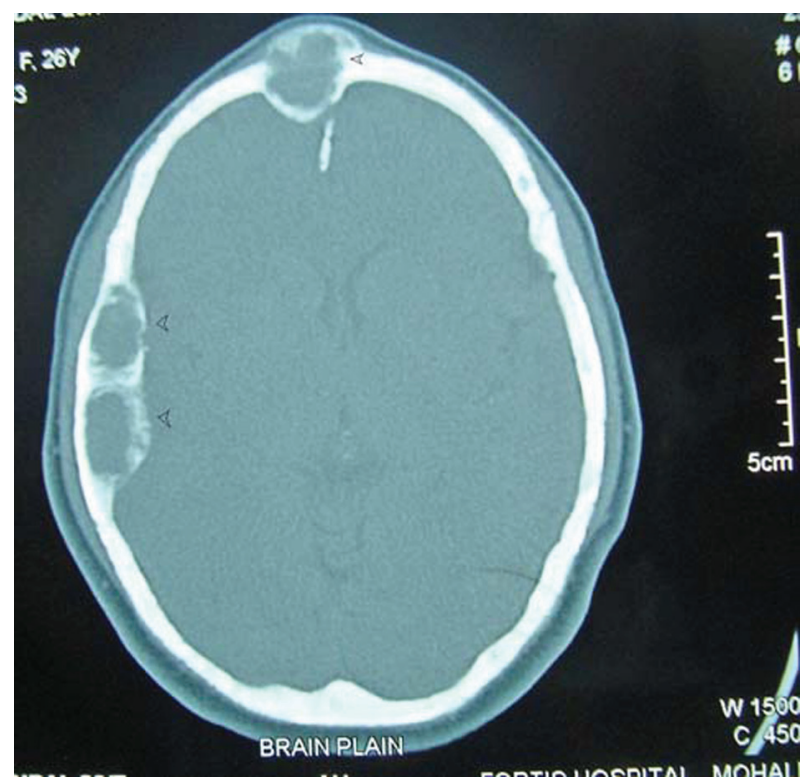

Figure 2 CT scan showing lytic bone lesions (arrowheads). 


\section{BMJ Case Reports}

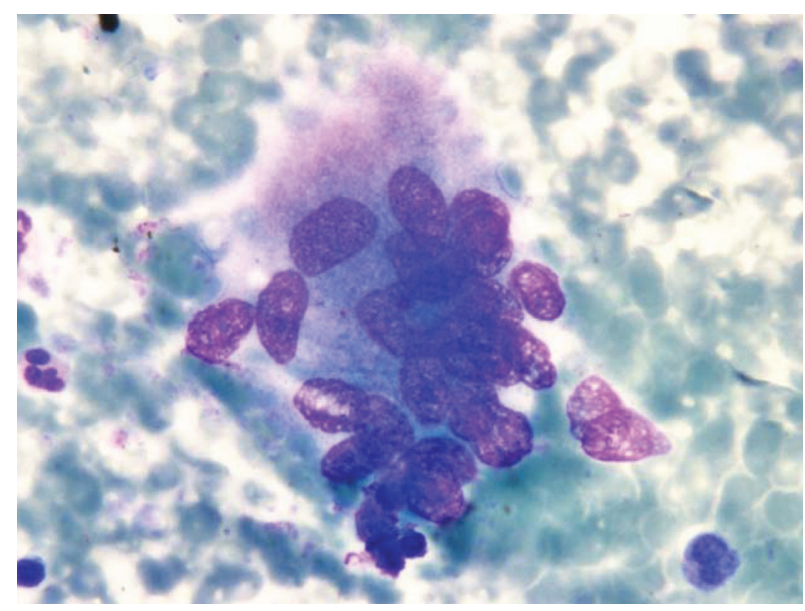

Figure 3 High power microscopy pictures of the fine needle aspiration cytology of the lytic bone lesion showing giant cells consistent with osteitis fibrosa cystica. simple bone cyst and metastatic bone disease. ${ }^{1-3}$ A calcium profile, x-rays of involved bones and FNAC should help clinch the diagnosis.

\section{Competing interests None.}

Patient consent Obtained.

\section{REFERENCES}

1. DiagnosisPro. Differential Diagnosis For Xray/Multiple lytic lesions of skull. http://en.diagnosispro.com/differential_diagnosis-for/xray-multiple-lyticlesions-of-skull/36613-154.html (accessed Sep 2009).

2. Head and Neck Surgery. Bony lesions of the skull. http://headnecksurgery wordpress.com/2009/02/05/bony-lesions-of-the-skull/ (accesed Sep 2009).

3. Guven GS, Beyazit Y, Kekilli M. Multiple lytic lesions on skull radiography: a diagnostic impasse. Eur J Intern Med 2005;16:622.

This pdf has been created automatically from the final edited text and images.

Copyright 2012 BMJ Publishing Group. All rights reserved. For permission to reuse any of this content visit http://group.bmj.com/group/rights-licensing/permissions.

BMJ Case Report Fellows may re-use this article for personal use and teaching without any further permission.

Please cite this article as follows (you will need to access the article online to obtain the date of publication).

Santosh R, Bhansali A, Rajwanshi A, Shah V, Behera A, Bhadada S. A bony swelling on the forehead: an uncommon manifestation of a well-known metabolic disease. BMJ Case Reports 2012;10.1136/bcr.09.2009.2318, Published XXX

Become a Fellow of BMJ Case Reports today and you can:

- Submit as many cases as you like

- Enjoy fast sympathetic peer review and rapid publication of accepted articles

- Access all the published articles

- Re-use any of the published material for personal use and teaching without further permission

For information on Institutional Fellowships contact consortiasales@bmjgroup.com

Visit casereports.bmj.com for more articles like this and to become a Fellow

Keep up to date with all published cases by signing up for an alert (all we need is your email address) http://casereports.bmj.com/cgi/alerts/etoc 